\title{
3. LITHOLOGY AND CLAY MINERALOGY OF SEDIMENTS FROM SITE 337, DSDP LEG 38
}

\author{
N.V. Renngarten, M.A. Rateev, V.D. Shutov, and V.A. Drits, \\ Geological Institute of the Academy of Sciences, USSR
}

\section{DESCRIPTIONS OF THE SEDIMENT SERIES}

The sediments cored at Site 337 to the depth of 180 meters are divided according to their lithologic and mineralogic characteristics into two series (Figure 1).

\section{Series 1 (0-42.2 m, Samples 2061-2081)}

Pelitomorphous clays with foraminiferal shells, coccolith marls, unsorted sand-silt-clays, rare tuff layers, and an absence of siliceous organisms. The series is divided into two subseries.

\section{Subseries 1 (0-28 m, Samples 2061-2076)}

Alternating slightly silty marls and foraminiferal clays with polymictic, unsorted sandy/clayey sediments with terrigenous material which includes: fragments of basalts, granites, hornblende and biotite schists, and quartzites. These were derived via ice-rafting.

\section{Clay Mineralogy}

Sediments of Subseries 1 (Pleistocene) contain in the clay fraction: illite, chlorite, montmorillonite, and a small amount of kaolinite (Table 1). The principal clay component is illite. The illite does not have expandable interlayers in its structure; the octahedral positions are predominantly populated by $\mathrm{Al}$ cations. This is a polytype $1 \mathrm{Md}$ modification, sometimes with an admixture of $1 \mathrm{M}$. The illite polytype was determined by the electron diffraction method of oblique structures, or with the aid of diffraction patterns of unoriented preparations preheated to $550^{\circ} \mathrm{C}$. The illite content in the subseries is constant and averages about $60 \%$.

A second clay component is chlorite with a maximum content of $30 \%$ or less. It belongs to the trioctahedral modification. Intensity ratios of the basal reflections (a low intensity of 001 and 003 reflections) indicate a heightened content of $\mathrm{Fe}$ cations in the octahedral structure, i.e., it is an Fe-chlorite. However, the mineral has a very low resistance to thermal treatment. After a sample is heated for $1 \mathrm{hr}$ at $550^{\circ} \mathrm{C}$, all reflections characteristic of chlorite disappear, or there are weak reflections at $d=13.2-13.6 \AA$. This indicates a defective structure and, specifically, an apparently "insular" (partly hydrated) structure of one-level brucite layers. The data obtained suggest that, to a large extent, the chlorite was formed as a result of structural alterations of biotite. The content of biotite in the sediments is high.

In this subseries, the montmorillonite content is insignificant, averaging $15 \%-20 \%$ with a maximum of $30 \%$. Another common clay mineral (Samples 2062, $2063,2067,2073$ ) is a mixed-layer clay with the following diffraction characteristics: the diffraction pattern of the untreated sample shows a broad continuous reflection, appearing as a "plateau," in the region of $d=11$ -
$14 \AA$; in the glycerine-saturated sample, the diffraction pattern shows a broad diffuse peak from 14 to $19 \AA$ with a maximum at $d \approx 17-18 \AA$. Also, the reflection at $d$ $\approx 4.7 \AA$ becomes broader. The data indicate the mixedlayer clay has montmorillonite layers with varying degrees of hydration alternating in its structure in an unordered fashion and in varying proportions. The degree of hydration, for the most part, is dependent upon the type of exchange cations. The cations seem, for the most part, to be $\mathrm{K}, \mathrm{Ca}$, and $\mathrm{Mg}$. After glycerine saturation, the montmorillonite layers expand to 17.7 $\AA$. However, the vermiculite interlayers which are saturated with $\mathrm{K}$ cations, expand to only $14 \AA$. Thus, it appears that after glycerine/saturation a mixed-layer phase of irregularly alternating 17.7 and $14 \AA$ layers is formed, with a prevalence of the $17.7 \AA$ layer. After heating, all layers contract to $9.6-9.8 \AA$. It is possible that the mineral is also a product of biotite disintegration. The transformation of biotite through vermiculite to dioctahedral montmorillonites is a well-known process and is a widespread occurrence in sedimentary rocks and weathering crusts.

Another modification of montmorillonite (Samples $2065,2066,2070$ ) is a mineral whose interlayers contain primarily $\mathrm{K}$ cations in the exchange state. Therefore, the diffraction pattern of an untreated sample has the montmorillonite reflection with $d=11 \AA$. This is often seen only as a background of heightened intensity, a "train" spreading out from the illite reflection (001) towards lower angles. However, the mineral retains its capacity to expand after saturation. The montmorillonite contains iron and dissolves in $1 \mathrm{~N} \mathrm{HCl}$. Two alternative explanations for the structural characteristics of this mineral are suggested: the montmorillonite is authigenic and developed from transformation of an alkaline pyroclastic mineral. Potassium accumulated either as a result of adsorption of these cations from seawater, or the $\mathrm{K}$ cations could have been supplied from the disintegration of basalt or basalt glass. If it is so, the process can be considered an "embryonic" form of glauconitization; however, it is more likely that the montmorillonites were also formed by the alteration of biotite. A portion of the $\mathrm{K}$ cations are removed from interlayers. The remaining ones cannot bond the silicate layers, and thus the layers become capable of expanding.

Subseries 2 (28-42.2 m, Samples 2077-2081)

A predominance of coccolith marls. A thin ash layer. No ice-rafted clastic material.

\section{Clay Mineralogy}

The clay fraction of Subseries 1 consists almost

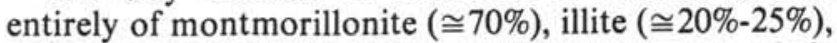
and kaolinite $(5 \%-10 \%)$ (Table 1). A characteristic 


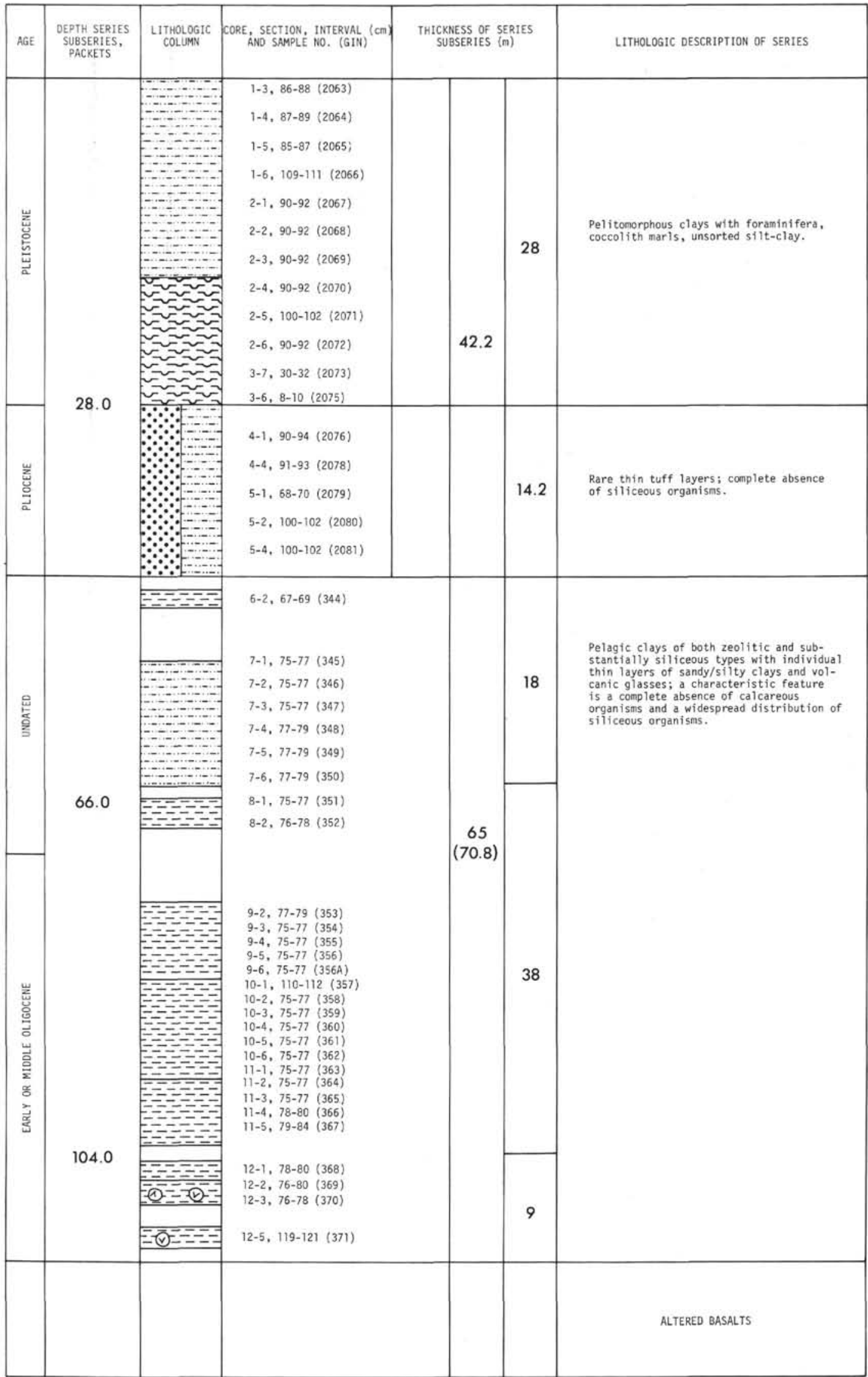

Figure 1. Stratigraphic column at Site 337, including lithologic descriptions and descriptions of clay minerals and clay mineral associations. 


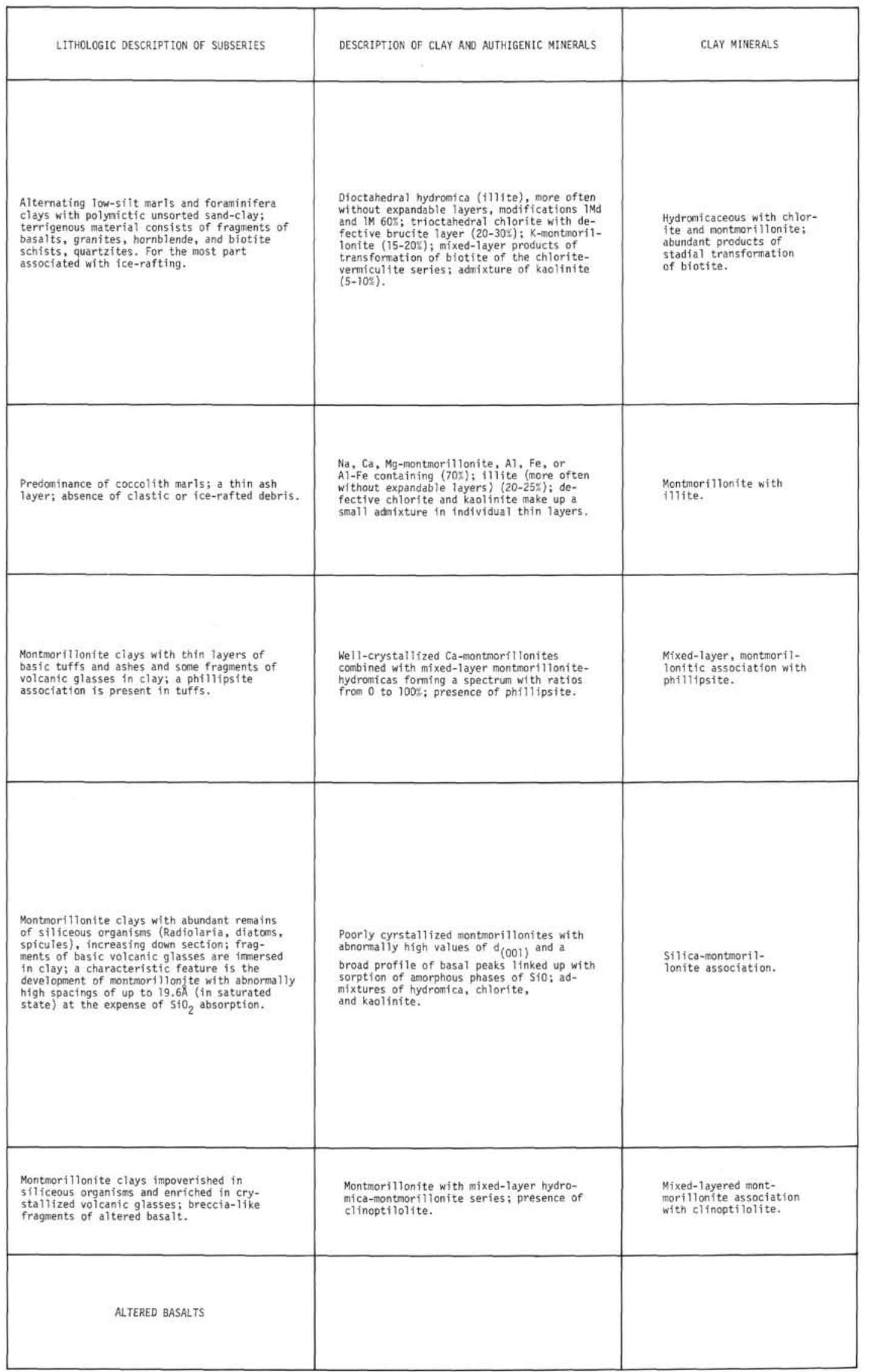

Figure 1. (Continued). 
TABLE 1

Data From X-Ray Analysis of Clay and Other Minerals, Site 337

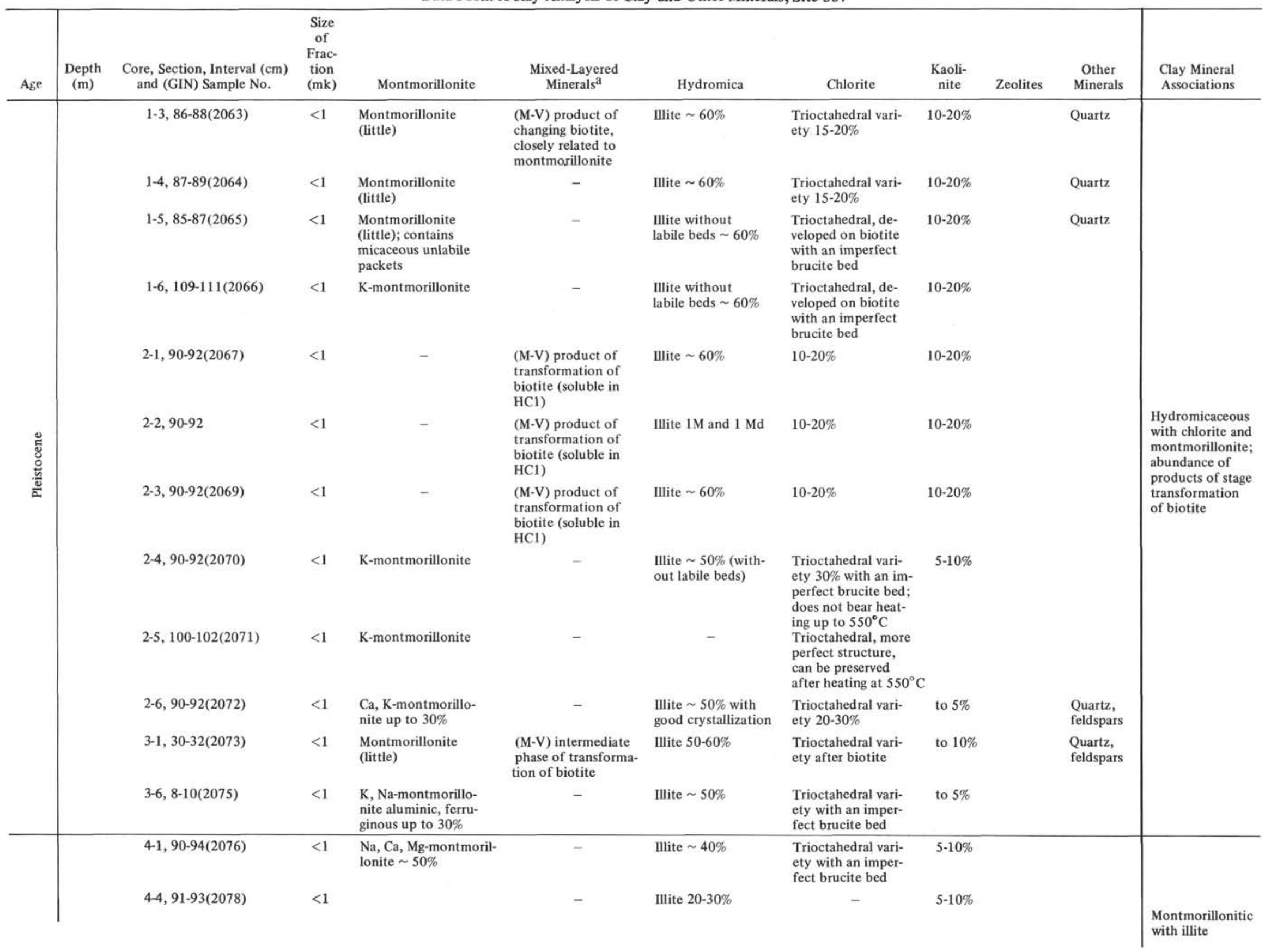




\begin{tabular}{|c|c|c|c|c|c|c|c|c|c|c|c|}
\hline \multirow{8}{*}{ 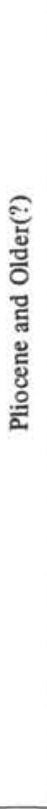 } & & $5-1,68-70(2079)$ & $<1$ & $\begin{array}{l}\text { Montmorillonite } \\
\text { aluminic up to } 70 \%\end{array}$ & - & Illite $20-30 \%$ & - & $5-10 \%$ & & & \multirow{8}{*}{$\begin{array}{l}\text { Mixed-layer } \\
\text { montmorillonitic } \\
\text { with phillipsite }\end{array}$} \\
\hline & & $5-2,100-102(2080)$ & $<1$ & $\begin{array}{l}\mathrm{Ca}, \mathrm{Mg} \text {-montmorillo- } \\
\text { nite slightly ferrugi- } \\
\text { nous } \sim 90 \%\end{array}$ & - & Illite $20-30 \%$ & - & - & $\begin{array}{l}\text { Abundance } \\
\text { of zeolite } \\
\text { on volcanic } \\
\text { glass }\end{array}$ & & \\
\hline & & $5-4,100-102(2081)$ & $<1$ & $\begin{array}{l}\text { Mg, Ca-montmorillo- } \\
\text { nite ferruginous } \\
\sim 90 \%\end{array}$ & - & - & Traces & - & & & \\
\hline & 50.2 & $6-2,67-69(344)$ & Rock & Calcic form $50-60 \%$ & $\begin{array}{l}\text { Spectrum from } 0 \text { to } \\
100 \%, 15-20 \%\end{array}$ & $\begin{array}{l}20 \% \text { labile interbeds } \\
\text { of montmorillontic } \\
\text { type } \sim 15 \%\end{array}$ & - & - & $\begin{array}{l}\text { Phillipsite } \\
10-15 \%\end{array}$ & $\begin{array}{l}\text { Quartz, } \\
\text { feldspars }\end{array}$ & \\
\hline & 58.7 & $7-3,75-77(346)$ & Rock & Calcic form $60-70 \%$ & $\begin{array}{l}\text { Spectrum from } 0 \text { to } \\
100 \% \sim 15 \%\end{array}$ & $\begin{array}{l}20 \% \text { labile interbeds } \\
\text { of montmorillonitic } \\
\text { type } \sim 10 \%\end{array}$ & - & - & - & $\begin{array}{l}\text { Quartz, } \\
\text { feldspars, } \\
\text { amorph. } \\
\mathrm{SiO}_{2}\end{array}$ & \\
\hline & 61.8 & $7-4,80-82(348)$ & $<10$ & Calcic form $75-80 \%$ & $\begin{array}{l}20 \% \text { interbeds of } \\
\text { hydromicaceous } \\
\text { type } \sim 10 \%\end{array}$ & Illitic type $\sim 10 \%$ & - & $5 \%$ & - & Quartz & \\
\hline & 63.3 & $7-5,77-79(349)$ & $<10$ & $\begin{array}{l}\text { Magnesium-calcic } \\
\text { form } \sim 80 \%\end{array}$ & Not over $69 \%$ & Illitic type $\sim 15 \%$ & - & - & - & Quartz & \\
\hline & 68.3 & $8-2,76-78(352)$ & Rock & $\begin{array}{l}\text { Sodium-magnesium- } \\
\text { calcic form } \sim 80 \%\end{array}$ & $\begin{array}{l}\text { Spectrum from } 0 \text { to } \\
100 \%, 15-20 \%\end{array}$ & $\begin{array}{l}20 \% \text { labile interbeds } \\
\text { of montmorillonitic } \\
\text { type } \sim 10 \%\end{array}$ & - & - & - & $\begin{array}{l}\text { Quartz, } \\
\text { feldspars, } \\
\text { amorph. } \\
\mathrm{SiO}_{2}\end{array}$ & \\
\hline \multirow{8}{*}{ 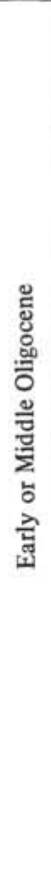 } & 79.3 & $9-3,75-77(354)$ & $<10$ & Calcic form $\sim 80 \%$ & $\begin{array}{l}15-20 \% \text { interbeds of } \\
\text { micaceous type } \\
\sim 10 \%\end{array}$ & Illitic type $\sim 15 \%$ & - & Little & - & $\begin{array}{l}\text { Quartz, } \\
\text { feldspars }\end{array}$ & \multirow{8}{*}{$\begin{array}{l}\text { Siliceous } \\
\text { montmorillonitic }\end{array}$} \\
\hline & 82.3 & $9-5,75-77(356)$ & $<10$ & Calcic form $\sim 80 \%$ & $\begin{array}{l}\text { Spectrum with } 20 \% \\
\text { interbeds of mica- } \\
\text { ceous type } \sim 10 \%\end{array}$ & Illitic type $\sim 10 \%$ & - & Little & - & $\begin{array}{l}\text { Quartz, } \\
\text { feldspars }\end{array}$ & \\
\hline & 87.3 & $10,275-77(358)$ & $<10$ & $\begin{array}{l}\text { Calcic, poorly crys- } \\
\text { tallized form with } \\
\text { adsorbed } \mathrm{SiO}_{2} \\
\sim 50 \%\end{array}$ & - & $\begin{array}{l}\text { Up to } 10 \% \text { of labile } \\
\text { interbeds of mont- } \\
\text { morillonitic type, } \\
30 \%\end{array}$ & $10 \%$ & $10 \%$ & - & $\begin{array}{l}\text { Quartz, } \\
\text { amorph. } \\
\mathrm{SiO}_{2}\end{array}$ & \\
\hline & 90.3 & $\begin{array}{c}10-4,75-77(360) \\
.\end{array}$ & $<10$ & $\begin{array}{l}\text { Poorly crystallized } \\
\text { with adsorbed } \mathrm{SiO}_{2} \\
\sim 60 \%\end{array}$ & - & $\begin{array}{l}\text { Up to } 10 \% \text { labile } \\
\text { interbeds of mont- } \\
\text { morillonitic type, } \\
30 \%\end{array}$ & $5-10 \%$ & $5-10 \%$ & - & $\begin{array}{l}\text { Quartz, } \\
\text { feldspar } \\
\text { amorph. } \\
\mathrm{SiO}_{2}\end{array}$ & \\
\hline & 93.3 & $10-6,75-77(362)$ & $<10$ & $\begin{array}{l}\text { Poorly crystallized } \\
\text { with adsorbed } \mathrm{SiO}_{2} \\
\sim 60 \%\end{array}$ & - & Illitic type $\sim 30 \%$ & $10 \%$ & $10 \%$ & - & $\begin{array}{l}\text { Quartz, } \\
\text { feldspars }\end{array}$ & \\
\hline & 95.3 & $11-1,75-77(363)$ & $<10$ & $\begin{array}{l}\text { Poorly crystallized } \\
\text { with adsorbed } \mathrm{SiO}_{2} \\
\sim 75 \%\end{array}$ & - & Illitic type $\sim 15 \%$ & $10 \%$ & Little & - & $\begin{array}{l}\text { Quartz, } \\
\text { feldspars }\end{array}$ & \\
\hline & 96.8 & $11-2,75-77(364)$ & Rock & $\begin{array}{l}\text { Poorly crystallized } \\
\text { with adsorbed } \mathrm{SiO}_{2} \\
\sim 75 \%\end{array}$ & - & $\begin{array}{l}\text { Up to } 20 \% \text { labile } \\
\text { interbeds of mont- } \\
\text { morillonitic type } \\
10-15 \%\end{array}$ & $5 \%$ & Little & - & $\begin{array}{l}\text { Quartz, } \\
\text { amorph. } \\
\mathrm{SiO}_{2}\end{array}$ & \\
\hline & 99.8 & $11-4,78-80(366)$ & $<10$ & $\begin{array}{l}\text { Poorly crystallized } \\
\text { with adsorbed } \mathrm{SiO}_{2} \\
\sim 60 \%\end{array}$ & - & Illitic type $30 \%$ & $10 \%$ & Little & - & $\begin{array}{l}\text { Quartz, } \\
\text { feldspars, } \\
\text { amorph. } \\
\mathrm{SiO}_{2}\end{array}$ & \\
\hline
\end{tabular}




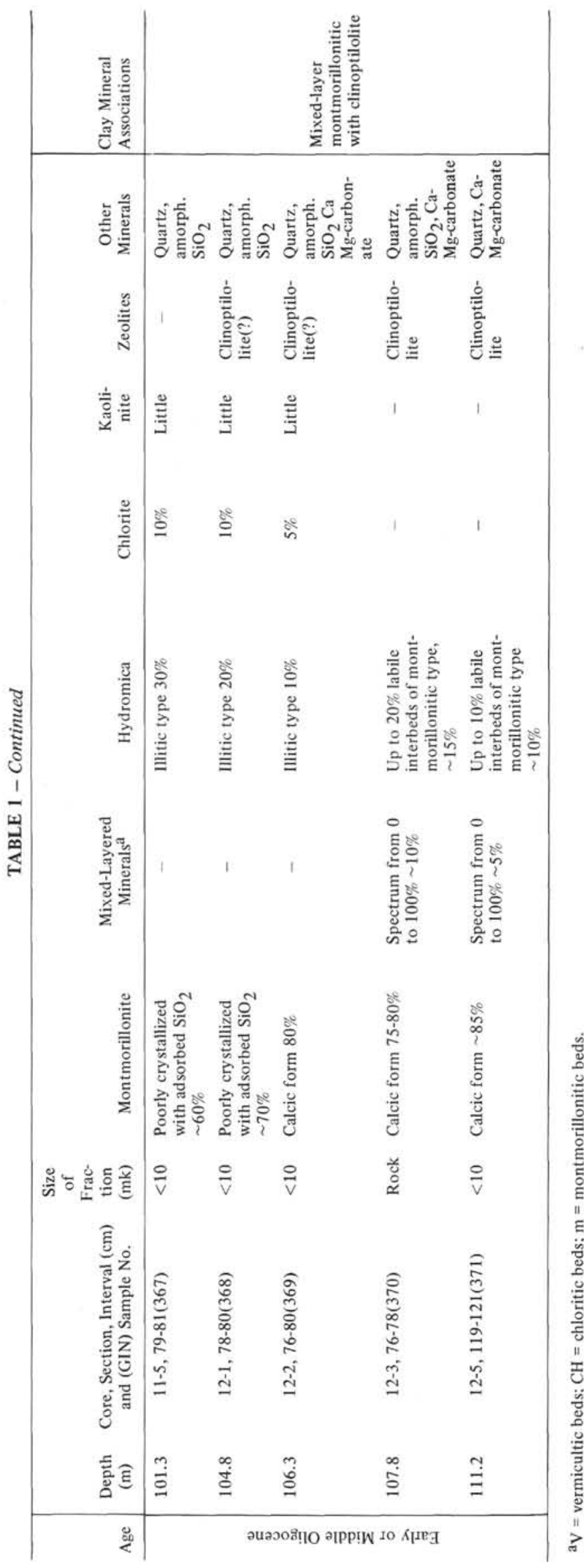

feature of the montmorillonites is a varying iron content in its structure. This mineral characteristic was qualitatively determined by the distribution of the basal reflections in the diffraction patterns of glycerinesaturated, and $550^{\circ} \mathrm{C}$ preheated samples. Diffraction patterns of strongly ferruginous montmorillonites, when saturated with glycerine, have a relatively low intensity of reflections ([004], [005] and [006]). Thus, they differ from the diffraction patterns of aluminum montmorillonites. Diffraction patterns of preheated samples give particularly clear data on the extent of the montmorillonite iron content. Strongly ferruginous montmorillonites have no reflection at $d(002) \cong 4.7-4.8 \AA$. In contrast, dehydrated aluminum varieties have a rather intense (002) reflection. An intermediate intensity corresponds to an intermediate iron content for the montmorillonite. Chemical analyses were available for some samples, which enabled a more reliable division of the montmorillonites according to their iron content (Table 2). They were divided into three groups: predominantly aluminum, aluminum-iron, and iron-containing.

Analysis of the data has shown that, in this subseries, montmorillonites of varying iron contents alternate. There is a relative increase in iron content (Samples 2079, 2082, 2080, 2078, 2081). The mica-like component of the subseries belongs either to nonexpanding illites, or to hydromicas. The hydromicas usually contain approximately $20 \%$ expandable interlayers. Chlorite, present in the subseries, is also trioctahedral with a defective brucite layer.

Series 2 (Cores 5-4 to 12-5, 42.4-113.0 m; early or middle Oligocene and Pliocene)

The series consists of a yellow, brown, gray, yellowish-orange clay, with rare, indistinct layers of sandy siltstones, volcaniclastic tuffs, and ashes. A zeolite mineralization is confined to the upper portion. The bulk of the sediments contains remains of siliceous organisms, which first appear in the upper part of the series, and are unvaryingly present to the base.

The clay, forming the bulk of sediments, is characteristic. It consists of Fe-montmorillonites (typical minerals of pelagic sediments) developed at the expense of the transformation (halmyrolysis) of tholeiitic basalts (Table 2, Samples 344, 346). Characteristics of this mineral group and their origin have been studied in detail on materials from DSDP Legs 2, 20, 27 (Kossovskaya and Shutov, 1975; Kossovskaya et al., 1963, 1975).

A distinctive montmorillonite was noted in Sample 344 , containing $18.56 \% \mathrm{Fe}_{2} \mathrm{O}_{3}$. This clay was formed by the accumulation of decomposed hyaloclastics, and a hydrothermal influx of ferruginous solutions. Another characteristic of this sample is the relatively high manganese content (to $0.28 \%$ ). The remaining samples of the entire series fall within the composition range of pelagic clay associated with the decay of basalt hyaloclastics. However, with increasing depth in the series, there is a slight increase in $\mathrm{Al}_{2} \mathrm{O}_{2}$ (15.63\% to $16.70 \%$ ), a drop in $\mathrm{Fe}_{2} \mathrm{O}_{3}(10.02 \%$ to $6.81 \%)$, and an increase in $\mathrm{K}_{2} \mathrm{O}(1.92 \%$ to $2.66 \%)$ and $\mathrm{Na}_{2} \mathrm{O}$ (3.73\% to $4.09 \%)$. 
TABLE 2

Chemical Composition of Samples, Site 337

\begin{tabular}{|c|c|c|c|c|c|c|c|c|c|c|}
\hline & \multicolumn{2}{|c|}{$<10 \mu \mathrm{m}$ Fraction } & \multicolumn{8}{|c|}{$\begin{array}{c}\text { Bulk Fractions } \\
\text { Series } 2 \\
\text { Early or Middle Oligocene and Pliocene }\end{array}$} \\
\hline & \multirow{2}{*}{$\begin{array}{l}\text { Subseries } 1 \\
2072\end{array}$} & \multirow{2}{*}{$\begin{array}{c}\text { Subseries } 2 \\
2077\end{array}$} & \multicolumn{4}{|c|}{ Subseries 2} & \multicolumn{2}{|c|}{ Subseries 2} & \multicolumn{2}{|c|}{ Subseries 3} \\
\hline & & & 344 & 344 & 346 & 346 & 352 & 352 & 370 & 370 \\
\hline $\mathrm{SiO}_{2}$ & 51.75 & 49.87 & 41.14 & 38.51 & 48.00 & 44.02 & 47.58 & 42.70 & 47.96 & 43.10 \\
\hline $\mathrm{TiO}_{2}$ & 0.98 & 1.20 & 1.34 & 1.41 & 1.05 & 1.13 & 1.22 & 1.35 & 1.12 & 1.23 \\
\hline $\mathrm{Al}_{2} \mathrm{O}_{3}$ & 17.30 & 15.38 & 12.11 & 12.73 & 14.39 & 15.63 & 14.70 & 16.27 & 15.15 & 16.70 \\
\hline $\mathrm{Fe}_{2} \mathrm{O}_{3}$ & 9.60 & 10.11 & 17.63 & 18.56 & 9.24 & 10.02 & 8.00 & 8.83 & 6.18 & 6.81 \\
\hline $\mathrm{FeO}$ & 0.79 & 0.42 & 0.17 & 0.18 & 0.14 & 0.15 & 0.71 & 0.78 & 0.24 & 0.26 \\
\hline $\mathrm{CaO}$ & 0.75 & 0.82 & 1.58 & 1.66 & 0.77 & 0.84 & 2.29 & 2.53 & 0.72 & 0.79 \\
\hline $\mathrm{MgO}$ & 2.64 & 2.10 & 3.16 & 3.32 & 3.26 & 3.54 & 3.30 & 3.64 & 3.69 & 4.05 \\
\hline $\mathrm{MnO}$ & 0.13 & 0.09 & 0.27 & 0.28 & 0.10 & 0.11 & 0.11 & 0.12 & 0.14 & 0.15 \\
\hline $\mathrm{Na}_{2} \mathrm{O}$ & 0.82 & 0.45 & 2.59 & 2.62 & 3.43 & 3.73 & 3.33 & 3.68 & 3.72 & 4.09 \\
\hline $\mathrm{K}_{2} \mathrm{O}$ & 3.24 & 0.96 & 1.87 & 1.90 & 1.77 & 1.92 & 1.85 & 2.04 & 2.41 & 2.66 \\
\hline $\mathrm{H}_{2} \mathrm{O}+$ & 6.25 & 8.10 & 7.75 & 8.15 & 1.91 & 2.08 & 4.69 & 5.18 & 7.18 & 7.80 \\
\hline $\mathrm{H}_{2} \mathrm{O}-$ & 5.26 & 9.19 & 9.79 & 10.29 & 8.69 & 9.45 & 7.51 & 8.28 & 8.03 & 8.84 \\
\hline $\mathrm{CO}_{2}$ & - & 0.42 & 0.09 & 0.09 & & & 0.24 & 0.26 & 0.34 & 0.37 \\
\hline $\mathrm{C}$ & 0.08 & 0.13 & & & 0.19 & 0.21 & 0.17 & 0.19 & & \\
\hline $\mathrm{P}_{2} \mathrm{O}_{5}$ & 0.21 & 0.80 & 0.18 & 0.19 & 0.05 & 0.05 & 0.20 & 0.22 & 0.07 & 0.08 \\
\hline $\mathrm{S}_{\mathrm{Fe}_{2}} \mathrm{~S}$ & & & & & 6.52 & 7.08 & 3.59 & 3.96 & 2.71 & 2.98 \\
\hline$\Sigma$ & 99.80 & 99.86 & 99.61 & 99.99 & 99.51 & 99.97 & 99.52 & 100.03 & 99.66 & 99.91 \\
\hline $\mathrm{SiO}_{2} \mathrm{gw}$ & 10.20 & - & 2.20 & & 5.94 & & 7.34 & & 7.42 & \\
\hline $\mathrm{SiO}_{2} \mathrm{am}$ & 1.75 & - & 2.21 & & 1.49 & & 1.50 & & 1.38 & \\
\hline
\end{tabular}

Note: Sample $2072=(2-6,100-102 \mathrm{~cm})$, silty clay; Pleistocene; Sample $2077=(4-2,30-32 \mathrm{~cm})$, tuff; Pliocene. Sample $344=(6-2,67-69 \mathrm{~cm})$, volcaniclastic tuff; Sample $346=(7-2,75-77 \mathrm{~cm})$, clay, pelagic, ferrimontmorillonitic; Sample $352=(8-2,76-78 \mathrm{~cm})$, clay, pelagic diatoms, ferrimontmorillonite; Sample $370=(12-3,76-78 \mathrm{~cm})$, clay, pelagic with zeolites.

The series is divided into three subseries based on the mineralogic composition of the sediments.

\section{Subseries 21 (Cores 5-4 to 7-6, 42.2-66.0 m)}

The upper boundary of the subseries is definite with overlying calcareous silts with foraminifera. The lower boundary is less distinct, overlying clays with an abundant siliceous microfossil content. The clays of Subseries 2, are yellow and often orange and brown. The upper part of the subseries contains volcaniclastic layers. The layers consist of aggregates, sometimes ferruginous glassy fragments, some altered to clay matter, and intergrown druses of phillipsite microcrystals. The phillipsite shows weak reflections $7.1,5.3,3.18$ on the X-ray pattern (Sample 344). In the other samples, the clay contains sand-size fragments of basic plagioclase, aggregate quartz grains, fragments of brown and light volcanic glasses, and small prismatic apatite crystals (Samples 346, 348). In the lower part of the subseries, there is a layer of volcanic glass (Sample 350 ), consisting of a slightly crystallized mass with a peculiar curvilinear "pale-like" structure. Fragments of hornblende crystals are present within the slightly crystallized glass.

\section{Clay Mineralogy}

The characteristics of the ferrimontmorillonites of this subseries are specific. They are marked by very high values of basal reflections at $d(001)=15.5-15.6 \AA$ in untreated samples, and high peaks with $d=18 \AA$ in saturated samples. This is a sign of a good mineral crystallization. The minerals belong to the $\mathrm{Ca}$ form. The heightened values of the basal reflection $(d=18 \AA)$ in glycerine-saturated samples may be attributed either to the overall finely dispersed nature of the mineral, or to the presence of mixed-layer clays. Apart from reflections with $d(002)=8.9 \AA-9 \AA$ belonging to the secondorder basal reflection of true montmorillonite, diffraction patterns of saturated samples show series of peaks in the 9.1-10.0 $\mathrm{A}$ interval. These reflections often merge to form a characteristic horizontal plateau (Sample 346). This suggests a continuous series of mixed-layer montmorillonite-hydromica units with a micaceous-toexpandable layer ratio varying from 0 to $10 \%$. The content of the mixed-layer phase does not exceed $10 \%-15 \%$. The usual weak resistance to acid treatment observed is also characteristic of the ferrimontmorillonite (Sample 348).

Along with montmorillonite and the series of mixedlayer clays genetically associated with it, there is also a true micaceous mineral present (Samples 347, 348). They are present in a limited quantity, not greater than $10 \%-15 \%$. There is also a small admixture of defective chlorite with reflection $d=13.6-13.8 \AA$. These are sometimes combined with $7.1 \AA$ on diffraction patterns of preheated samples, and a $7 \AA ̊$ mineral preserved after boiling the samples in $10 \% \mathrm{HCl}$ (kaolinite) (Sample 348). 


\section{Subseries 22 (Cores 8-1 to 11-5, 66.0-104.0 m)}

The subseries consists of light-yellow, gray and brown-gray carbonate-free clays, with abundant remains of siliceous microfossils (Radiolaria, diatoms, and sponge spicules). These are present in the clay and increase with depth to the base of the subseries. The clay is a fine-aggregate and often nearly isotropic. Along with siliceous skeletons, the sediment contains numerous fragments of various volcanic glasses. Brown, diverse volcanic glass fragments $(N=1.605-$ $1.610)$ prevail. They are characterized by angular contours, with a vesicular surface and rugged edges. In samples where they are especially abundant, there are also large fragments of fresh basic plagioclase crystals (Sample 354).

\section{Clay Mineralogy}

The clay retains a montmorillonitic composition, but its character is substantially altered. In the upper part of the subseries, where siliceous organisms are abundant, montmorillonite is represented by a wellcrystallized Ca-form with a mixed-layer unit (Samples $352,354,356)$. However, lower in the section it is replaced by a poorly crystallized form. The latter has abnormally high values of $d\left({ }_{001}\right)$, and wide basal peak profiles equal (in the saturated state) to 18.8-19.2 $\AA$. There also is a typical broad halo in the 3.0-4.5 region, associated with an abundance of amorphous material (uncrystallized glass or opal, Samples 160, 162, 164). Abnormally high values of basal reflections and their diffuse shape are very probably due to the sorption, by montmorillonite, of amorphous $\mathrm{SiO}_{2}$. Samples boiled in soda indicate a distinctly decreased spacing of $d(001)$, and an improved overall configuration. However, even in this "regenerated" form, the montmorillonite of this subseries differs noticeably from its counterpart in the upper part of the subseries. It retains its poor crystallization and is devoid of any mixed-layer units. There is a further tendency for it to lose its iron content and to gain in $\mathrm{SiO}_{2}$ (Table 2, Sample 252). Accessory clay minerals include: illite-type hydromica, defective chlorite, and kaolinite. This association is found with pelagic, essentially siliceous sedimentation, where, with authigenic forms of disorderly montmorillonite, terrigenous admixtures of other clay minerals are also deposited.

\section{Subseries 33 (Cores 12-1 to 12-5, 104-113.0 m)}

The subseries is thin and consists of light, grayishbrown clays, frequently deformed, and often transformed into a breccia together with small fragments of the altered basement basalt. The basic sediment nature is often nonuniform. Remnants of siliceous organisms decrease noticeably. Only large Radiolaria chambers are sporadically present. The sediment includes abundant fragments of crystallized glasses, quartz and feldspar grains, shreds of montmorillonite-chlorite aggregates, sometimes with very fine zeolite (?) microcrystals derived from altered underlying basalts. In the diffraction patterns of the clay and clay fractions, reflections with $d=2.97-2.98 \AA$ are constantly recorded. These belong to a Ca-Mg carbonate, also derived from the altered basalt basement (Samples 369, 371).
The chemical analysis of clay from the least altered parts of the core indicates a decrease in iron content and an increased silica content (Table 2, Sample 270). However, the clay as a whole is characterized by a sharp predominance of well-crystallized montmorillonite of the $\mathrm{Ca}$-form in combination with a series of mixed-layer units genetically related to it. In the mixed-layer clays, interlayering units dominate in which a micaceous phase is present in amounts of $10 \%$ $20 \%$ to $90 \%$. This is expressed in the diffraction patterns of saturated samples by characteristic sharp peaks with $d=9.1-9.3 \AA$ and $d=9.8-9.9 \AA$ (Samples 368, 369, 370). Sometimes weak reflections with $d=8.9,7.6,3.19 \AA$ are present, suggesting zeolites of the clinoptilolite series.

On the whole, the mineral association of the subseries shows noticeable traces of interaction of the sediments with the underlying basement of hydrothermally altered basalt.

\section{PRINCIPAL RESULTS AND CONCLUSIONS}

1. Two sediment series corresponding to DSDP unit subdivisions have been identified and investigated. A more detailed subdivision of the series into subseries based on mineralogic data has been discussed.

2. Although Site 337 is located on the top of rift mountains at the eastern edge of "extinct axis" in the Norwegian Basin, the location did not have a significant effect on the sedimentation of the Pleistocene deposits. The sediments were derived via ice-rafting and erosion of the floor of the Norwegian Basin.

An intensive supply of "exotic" sedimentary material by ice-rafting is apparent by the abundance in Pleistocene deposits of unsorted sand-silt and clays, with pebbles of granites, siltstones, limestones, biotite, and amphibolite schists. A higher sedimentation rate is indicated in the "Glacial" as compared with the Tertiary.

This sedimentation, associated with "glaciation" has affected the formation of the clay minerals in the Pleistocene section. A major role was played by the sediment components supplied by ice-rafting, specifically the abundance of micas which made up to $70 \%$ of the clay fraction. They are represented by dioctahedral illite-type hydromica (predominantly without expandable layers or rarely with more than 10\%-20\% expandable layers). The polytype modification of hydromicas is mostly $1 \mathrm{Md}$, and partly $1 \mathrm{M}$.

Biotite schists with unstable trioctahedral micas were an especially important component. These micas were transformed to a series of alteration products: mixedlayer vermiculite-montmorillonite minerals, defective chlorites, and K-montmorillonites. Petrographic observation also shows all stages of corrosion and alteration of the biotite plates in situ, and fully corroborates Xray data. The presence of this clay minerals assemblage with hydromica, chlorite, an admixture of montmorillonite, kaolinite, and mixed-layer units (with the same ratio of components) was previously noted in the redeposited glacial sediments in the Barents and White seas (Rateev, 1949; Kalinenko and Rateev, 1974). This is the basis for the conclusions that in the Pleistocene clay minerals were ice-transported to the NorwegianGreenland Sea, either from the north (Spitsbergen) or 
from the east (Scandinavia). A study of the clay minerals distribution by sediment types indicated that the pelagic sediments of the Oligocene/Pliocene have a montmorillonite composition for the clay fraction, frequently with zeolite. However, in the Pleistocene sediments the clay fraction has hydromicas $(60 \%)$, and chlorite, with admixture of vermiculitemontmorillonite mixed-layer units $(30 \%)$.

Therefore, the ice transport of clastic and clay minerals and the abundance of biotite are the main characteristics of the Pleistocene sediments. Clastic clay material was supplied extensively during the interglacial periods. During these periods, the hydromica composition of the clay fraction of the Pleistocene sediments was drastically increased. However, during the periods of glaciation volcanogenic montmorillonite increased. This is not a universal, world-wide phenomenon. For example, in the Black Sea, Stoffers and Muller (1972) established an inverse relationship. In the Black Sea sediments of the "glacial" epoch, an increase of montmorillonite was noted.

3. Series 2 consists of typical pelagic clays, containing abundant remains of siliceous microfossils in the middle subseries. The clay minerals formed by alteration of hyaloclastics and pyroclastics of tholeiitic basalts, and represented by characteristic ferrimontmorillonite. It is characterized by a high iron content $\left(\mathrm{Fe}_{2} \mathrm{O}_{3}\right.$ to $\left.10.5 \%\right)$, an approximately equal proportion of $\mathrm{K}_{2} \mathrm{O}$ and $\mathrm{Na}_{2} \mathrm{O}$, and a very low resistance to acid treatment. With increasing depth in the series section, a slight drop in iron content and an increase in silica and in the sum total of alkalis was observed (see Table 2). Despite a similar chemical composition and that all ferrimontmorillonites belong to the Ca-form marked by high values of basal reflection with $d(001)=15-16 \AA$, two mineral types are clearly discernible.

The first is characterized by a high degree of crystallization and a presence of genetically related peculiar series of mixed-layer hydromica-mont- morillonite units with a "complete set" of mica-toexpandable layer ratios varying from 0 to $100 \%$. The other mineral which is present only in the middle, siliceous subseries is free of any mixed-layer units and is poorly crystallized. Characteristics of the basal reflection (up to $19.8 \AA$ in saturated samples) indicates a "littering" of the montmorillonite interlayers with amorphous silica.

4. Volcaniclastic tuffs and clays with phillipsite are present at the boundary between the subseries. Femontmorillonite has a high $\mathrm{Fe}_{2} \mathrm{O}_{3}$ content $(18.55 \%)$ (Table 2). It was formed as a result of inflow of ironcontaining solution enriched in manganese. The manganese is present in the clay, and as isolated manganese concretions at the interface between series.

\section{REFERENCES}

Kalinenko, V.V. and Rateev, M.A., 1974. Clay minerals in sediments of the White Sea: Litologiya i Poleznye iskopaemye, v. 4, p. 10-23.

Kossovskaya, A.G. and Shutov, V.D., 1975. Mineralsindicators of geotectonic types of the regional epigenesis and its conjugation with metamorphism on continents and in oceans. Crystallochemistry of minerals and geological problems: Moscow (Nauka), p. 19-35.

Kossovskaya, A.G., Drits, V.A., and Alexandrova, V.A., 1963. On trioctahedral micas in sedimentary rocks: Intern. Clay Conf. Proc., Stockholm (Pergamon Press), p. 147169.

Kossovskaya, A.G., Gushchina, E.B., Drits, V.A., Dmitrik, A.L., Lomova, O.S., and Serebryannikova, N.A., 1975. Mineralogy of Mesocenozoic deposits of the Atlantic Ocean (according to the materials of Leg 2 of Glomar Challenger): Litologiya i poleznye iskopaemye, no. 6, p. 12-35.

Rateev, M.A., 1949. Mineralogical composition of the clay fraction of recent sea sediments: State Oceanogr. Inst. Proc., v. 5, p. 89-115.

Stoffers, P. and Müller, G., 1972. Clay mineralogy of Black Sea sediments: Sediment. Holland, v. 18, p. 113-121. 